\title{
Productivity, Quality and Profitability of Okra (Abelmoschus esculentus) as Influenced by Organic Manures and Biofertilizers
}

\author{
Jitendra Singh Bamboriya ${ }^{1}$, S. R. Naga ${ }^{2}$, S. R. Sharma ${ }^{3}$, M. R. Choudhary and S. D. Bamboriya ${ }^{4}$ \\ ${ }^{1,283}$ Dept. of Soil Science, ${ }^{4}$ Dept. of Horticulture, S.K.N.A.U., Jobner, Rajasthan (303 329), India \\ ${ }^{5}$ Dept. of Agronomy, AU, Jodhpur, Mandor, Rajasthan (342 304), India
}

\author{
Corresponding Author \\ S. D. Bamboriya \\ e-mail: sumisaani@gmail.com
}

\author{
Article History \\ Article ID: AR1889 \\ Received in $22^{\text {nd }}$ July, 2018 \\ Received in revised form $17^{\text {th }}$ August, 2018 \\ Accepted in final form $19^{\text {th }}$ August, 2018
}

\begin{abstract}
The present experiment was conducted at Horticultural Research Farm, Sri Karan Narendra College of Agriculture, Jobner, Rajasthan, India during kharif, 2017. The experiment was conducted in a randomized block design with sixteen treatments replicated thrice. The treatments include organic manures (control, FYM @ $20 \mathrm{t} \mathrm{ha}^{-1}$, vermicompost @ $6 \mathrm{t} \mathrm{ha}^{-1}$ and poultry manure @ $8 \mathrm{t} \mathrm{ha}^{-1}$ ) with biofertilizers (control, Azospirillum, PSB and Azospirillum+PSB). The results showed that application of vermicompost @ $6 \mathrm{t} \mathrm{ha}^{-1}$ significantly increased yield plant $^{-1}$ $(311.46 \mathrm{~g})$, ha $^{-1}(141.48 \mathrm{q})$ and picking ${ }^{-1}(6.11 \mathrm{~kg})$ of okra. However, among the quality parameters the highest protein (1.97\%) content and the lowest crude fiber content (1.54\%) of fruit recorded under vermicompost which was at par with poultry manure. The highest nitrogen $(0.315 \%)$, phosphorus $(0.653 \%)$ and potassium (1.761\%) content and uptake of nitrogen (45.81 kg ha $\left.{ }^{-1}\right)$, phosphorus $\left(93.91 \mathrm{~kg} \mathrm{ha}^{-1}\right)$ and potassium ( $253.28 \mathrm{~kg} \mathrm{ha}^{-1}$ ) also observed in vermicompost closely followed by poultry manure treatment. The maximum net returns (Rs 205928 ha $^{-1}$ ) were obtained with vermicompost whereas poultry manure was superior in Benefit-cost ratio with the value 3.01. Among different biofertilizers combined use of Azospirillum+PSB recorded significantly higher yield (326.01 $\mathrm{g} \mathrm{plant}^{-1}, 134.91 \mathrm{q} \mathrm{ha}{ }^{-1} \mathrm{and} 5.83 \mathrm{~kg}$ picking $^{-1}$ ) quality parameters (protein \%); nitrogen, phosphorus, potassium content and uptake; net returns (₹ 207634 ha $^{-1}$ ) and Benefitcost ratio (3.36) of okra and the lowest crude fibre. Whereas superior values regarding the yields observed in the treatment receiving the combination of vermicompost @ $6 \mathrm{t} \mathrm{ha}^{-1}$ and Azospirillum+PSB.
\end{abstract}

Keywords: Okra, organic manures, biofertilizers, productivity, quality, profitability

\section{Introduction}

Okra [Abelmoschus esculents (L.) Moench] is an important vegetable crop in India. Nutritional requirement of okra is very high due to its short duration and hence usually chemical fertilizers are used for vegetable production. Inadequate or imbalanced nutrient supply is one of the major constraints in harvesting higher yields. The deteriorating productivity of crops has been found to be associated with deterioration of soil physical and biological qualities besides imbalance in micronutrients (Parmar, 2014). Inorganic fertilizer are not helpful in intensive agriculture due to reduced crop yield, soil acidity and nutrients imbalance (Ojoniyi, 2000). Substitution of high analysis fertilizers for enhancing crop productivity or insufficient use of organic sources of plant nutrients have rendered most of the Indian soils deficient in macro and micro nutrients (Acharya and Mandal, 2002). Thus there is an emergent need to utilize other sources of plant nutrients for sustainable okra production.

Organic manures being helpful in building a strong organic matter base, resulting in improvement of soil structural properties like bulk density, porosity, aeration and water holding capacity, regulates soil pH near neutral, maintains soil health, enhances biological diversity and soil micro-flora, reduces nutrient leaching, increase availability and uptake of nutrients leading to sustainable vegetable production, devoid of harmful residues (Acharya and Mandal, 2002). Organic manures also improve the quality of vegetables (Chattoo et al., 2003), increase protein content (Latrach et al., 2014) and also enhance the physiological efficiency of okra (Paramasivan, 2005). Nitrogen from organic manures is released slowly (25-50\% in first year) and recovery of $P$ is slightly better than from fertilizers (Gopalakrishnan, 2007). In this way they play a significance role in sustainable agriculture (Subbarao et al., 2001).

Biofertilizers are carrier based micro-organisms which help to enhance productivity by biological nitrogen fixation or solubilization of insoluble phosphate or by producing hormones, vitamins and other growth promoters required for plant growth (Bhattacharyya et al., 2000; Kızılkaya, 2008) 
and suppress the incidence of pathogen and control diseases (Bagyaraj, 2003). They influence the total soil microflaura, soil enzyme activity and in turn soil health (Dar et al., 2010).

Combined or sole application of organic manures and biofertilizers increases yield and improves the quality attributes in vegetables (Verma et al., 1997; Bahadur et al., 2006). The integration has proved superior to individual components separately with respect to yield, quality and nutrient uptake (Chatoo et al., 2003). In this context the present study was conducted to assess the effect of organic manures and biofertilizers on productivity, quality and profitability of okra.

\section{Materials and Methods}

A field experiment was conducted during the kharif season of 2017 at the Horticulture farm, S.K.N. College of Agriculture, Jobner (Rajasthan), India to evaluate productivity, quality and profitability of okra as influenced by organic manures and biofertilizers. The soil was loamy sand in texture, having slight alkaline reaction ( $\mathrm{pH} 8.1$ ), low in available nitrogen (124.74 $\mathrm{kg} \mathrm{ha}^{-1}$ ), medium in available phosphorus (18.84 $\mathrm{kg} \mathrm{ha}^{-1}$ ) and potassium (147.50 kg ha-1). The experiment was consisted of four levels of organic manures (control, FYM @ $20 \mathrm{t} \mathrm{ha}^{-1}$, vermicompost @ 6 t ha-1 and poultry manure @ 8 t ha ${ }^{-1}$ ) and four levels of biofertilizers (control, Azospirillum, PSB and Azospirillum+PSB) in randomized block design. Okra variety 'Arka Anamika' was sown at $60 \times 45 \mathrm{~cm}^{2}$ row to row and plant to plant spacing on $28^{\text {th }}$ July, 2017 with a seed rate of $15 \mathrm{~kg}$ $\mathrm{ha}^{-1}$. Total pickings were seven in number which measured in $\mathrm{kg}$. All the biometrical observation on crop were observed as per the standard practices. Economics of treatments was computed on the basis of prevailing market price of inputs and outputs in okra under each treatment. The analysis of protein content by nitrogen \% in fruit determined by Kjeldahl's method was multiplied by 6.25 multiplication factor and crude fibre content was determined with the help of acid-alkali method given by Chopra and Kanwar (1983).

\section{Results and Discussion}

\subsection{Effect of organic manures}

In this present investigation yield, quality parameters and economics of okra differs significantly due to the application of organic manures and biofertilizers (Table 1 and 2). The highest fruit yield plant ${ }^{-1}$ (311.46 g), ha-1 (141.48 q) and picking ${ }^{-1}$ $(6.11 \mathrm{~kg})$ was obtained with application of vermicompost @ 6 t ha $^{-1}$. Nitrogen $(0.315 \%)$, phosphorus $(0.653 \%)$, potassium

\begin{tabular}{|c|c|c|c|c|c|c|c|c|}
\hline $\begin{array}{l}\text { Sl. } \\
\text { No. }\end{array}$ & Treatment & $\begin{array}{l}\text { Fruit yield } \\
\text { plant }^{-1}(\mathrm{~g})\end{array}$ & $\begin{array}{l}\text { Fruit yield } \\
\text { ha }^{-1}(\mathrm{q})\end{array}$ & $\begin{array}{l}\text { Average fruit } \\
\text { yield picking }{ }^{-1} \\
\text { (kg) }\end{array}$ & $\begin{array}{l}\text { Protein } \\
\text { content } \\
(\%)\end{array}$ & $\begin{array}{l}\text { Crude } \\
\text { fibre con- } \\
\text { tent (\%) }\end{array}$ & $\begin{array}{l}\text { Net } \\
\text { returns } \\
\left(₹ \mathrm{ha}^{-1}\right)\end{array}$ & $\begin{array}{l}\mathrm{B}: \mathrm{C} \\
\text { ratio }\end{array}$ \\
\hline \multicolumn{9}{|c|}{ A. Organic manures } \\
\hline 1. & Control & 209.08 & 81.29 & 3.51 & 1.16 & 2.08 & 117832 & 2.63 \\
\hline 2. & FYM @ 20 t ha-1 & 255.73 & 118.78 & 5.13 & 1.54 & 1.74 & 176610 & 2.90 \\
\hline 3. & Vermicompost @ 6 t ha-1 & 311.46 & 141.48 & 6.11 & 1.97 & 1.54 & 205928 & 2.67 \\
\hline 4. & Poultry manure @ 8 t ha $^{-1}$ & 290.96 & 130.93 & 5.66 & 1.84 & 1.60 & 196551 & 3.01 \\
\hline & SEm \pm & 7.09 & 0.92 & 0.04 & 0.08 & 0.06 & 1834 & 0.03 \\
\hline & $\mathrm{CD}(p=0.05)$ & 20.49 & 2.65 & 0.11 & 0.23 & 0.18 & 5298 & 0.09 \\
\hline \multicolumn{9}{|c|}{ B. Bio-inoculants } \\
\hline 1. & Control & 215.81 & 93.99 & 4.06 & 0.98 & 2.03 & 126147 & 1.95 \\
\hline 2. & Azospirillum & 265.87 & 122.64 & 5.30 & 1.79 & 1.69 & 183250 & 2.97 \\
\hline 3. & PSB & 259.53 & 120.94 & 5.22 & 1.69 & 1.77 & 179890 & 2.92 \\
\hline \multirow[t]{3}{*}{4.} & Azospirillum+PSB & 326.01 & 134.91 & 5.83 & 2.05 & 1.47 & 207634 & 3.36 \\
\hline & SEm \pm & 7.09 & 0.92 & 0.04 & 0.08 & 0.06 & 1834 & 0.03 \\
\hline & $\mathrm{CD}(p=0.05)$ & 20.49 & 2.65 & 0.11 & 0.23 & 0.18 & 5298 & 0.09 \\
\hline
\end{tabular}

(1.761\%) and protein (1.97\%) content; N (45.81), P (93.91) and $\mathrm{K}\left(253.28 \mathrm{~kg} \mathrm{ha}^{-1}\right)$ uptake were significantly increased with vermicompost treatment and lowest fiber content (1.54\%) was recorded in same treatment. The highest net returns ( $₹ 205928$ ha $^{-1}$ ) were observed in $M_{2}$ whereas benefit:cost ratio (3.1) was under poultry manure treatment. The higher value of net returns recorded under treatments receiving vermi-compost is attributed to a distinctly higher fruit yield giving the highest gross returns. Application of vermicompost might have the ability to increase the availability of nutrients probably due to higher rate of mineralization and favourable condition for microbial and chemical activity, which in turn increased the N, P, K and protein content and NPK uptake in okra fruits. The increase in protein content might be due to 


\begin{tabular}{|c|c|c|c|c|c|c|c|}
\hline $\begin{array}{l}\text { Sl. } \\
\text { No. }\end{array}$ & Treatment & $\begin{array}{c}\mathrm{N} \text { content } \\
(\%)\end{array}$ & $\begin{array}{c}\text { P content } \\
(\%)\end{array}$ & $\begin{array}{c}\mathrm{K} \text { content } \\
(\%)\end{array}$ & $\begin{array}{c}\text { N uptake } \\
\left(\mathrm{kg} \mathrm{ha}^{-1}\right)\end{array}$ & $\begin{array}{l}\text { P uptake } \\
\left(\mathrm{kg} \mathrm{ha}^{-1}\right)\end{array}$ & $\begin{array}{l}\mathrm{K} \text { uptake } \\
\left(\mathrm{kg} \mathrm{ha}^{-1}\right)\end{array}$ \\
\hline \multicolumn{8}{|c|}{ A. Organic manures } \\
\hline 1. & Control & 0.185 & 0.590 & 1.239 & 16.10 & 48.55 & 101.55 \\
\hline 2. & FYM @ 20 t ha ${ }^{-1}$ & 0.246 & 0.619 & 1.393 & 29.87 & 72.78 & 166.25 \\
\hline 3. & Vermicompost @6 tha-1 & 0.315 & 0.653 & 1.761 & 45.81 & 93.91 & 253.28 \\
\hline 4. & Poultry manure @ 8 t ha $^{-1}$ & 0.295 & 0.641 & 1.568 & 39.13 & 83.90 & 208.05 \\
\hline & $\mathrm{SEm} \pm$ & 0.013 & 0.006 & 0.052 & 1.80 & 0.75 & 7.78 \\
\hline & $C D(p=0.05)$ & 0.036 & 0.017 & 0.151 & 5.20 & 2.18 & 22.47 \\
\hline \multicolumn{8}{|c|}{ B. Bio-inoculants } \\
\hline 1. & Control & 0.156 & 0.598 & 1.301 & 15.84 & 57.66 & 127.56 \\
\hline 2. & Azospirillum & 0.287 & 0.618 & 1.506 & 35.97 & 76.02 & 188.48 \\
\hline 3. & PSB & 0.270 & 0.635 & 1.460 & 34.07 & 76.84 & 180.21 \\
\hline 4. & Azospirillum+PSB & 0.327 & 0.652 & 1.695 & 45.03 & 88.62 & 232.88 \\
\hline & SEm \pm & 0.013 & 0.006 & 0.052 & 1.80 & 0.75 & 7.78 \\
\hline & $C D(p=0.05)$ & 0.036 & 0.017 & 0.151 & 5.20 & 2.18 & 22.47 \\
\hline
\end{tabular}

more availability of $\mathrm{N}$ with the application of vermicompost over rest of the treatments. The better supply of $\mathrm{N}$ might have helped in better absorption and utilization of all plant nutrients and a large proportion of photosynthesis might have diverted to protein formation. Similar results of higher productivity and profitability by using vermicompost were reported by Sharma et al. (2014); Yadav et al. (2016).

\subsection{Effect of biofertilizers}

The combined application of Azospirillum with PSB could bring significant differences on yield, quality parameters and economics of okra. The highest yield plant ${ }^{-1}$ (326.01g), ha $^{-1}(134.91 \mathrm{q})$ and picking ${ }^{-1}(5.83 \mathrm{~kg})$ of okra was recorded in Azospirillum+PSB. Among various treatments tested, the maximum net returns ( $₹ 207634 \mathrm{ha}^{-1}$ ) and $B: C$ ratio of 3.36 was recorded under the same treatment. Azospirillum with PSB was superior in nutritional parameters (protein content) and in nutrient (N, P \& K) content and uptake whereas crude fibre content was lowest (1.47\%). Increased yield attributes in Azospirillum with PSB treatment might be due to the additive effect of biofertilizers which might have provided better soil conditions inclusive of improved soil fertility, nitrogen fixation, phosphate solubilization, enhanced the efficacy of applied $\mathrm{N}$ and $\mathrm{P}$; enhanced the activities of other microbes and also released of growth stimulants. The better supply of $\mathrm{N}$ might have also helped in better absorption and utilization of all plant nutrients and a large proportion of photosynthesis might have diverted to protein formation. Active and rapid multiplication of microorganisms in rhizosphere creating a favourable condition for nutrient availability and secretion of hormones like IAA, cytokinin, GA (Bahadur and Manohar, 2001).
Further, this is clearly indicated that a synergistic interaction between organic manures and biofertilizers which have resulted in enhanced yield parameters which ultimately increased fruit yield. So production potential of okra crop can be improved with integrated use of organic manures with biofertilizers.

\section{Conclusion}

Application of vermicompost @ $6 \mathrm{t} \mathrm{ha} a^{-1}$ appeared best in respect of yield sustainability, quality and profitability of okra over rest of the treatments. Azospirillum inoculated with PSB proved its superiority in respect of the yield, quality and macronutrient content $(\mathrm{N}, \mathrm{P}, \mathrm{K})$ of the plants.

\section{References}

Acharya, C.L., Mandal, K.G., 2002. Integrated plant nutrient supply in vegetable crops. In: Compendium recent advances in vegetable production technology. proceedings of winter school, 3-23 December, 2002, Indian Institute of Vegetable Research, Varanasi (UP), 79-104.

Bagyaraj, D.J., 2003. Biofertilizers: Present position and future prospective. Biofertilizer News Letter, 3-7.

Bahadur, A., Manohar, R.K., 2001. Response of okra to biofertilizers. Vegetable Science 28(2), 197-198.

Bahadur A., Singh J., Singh K.P., Rai, M., 2006. Plant growth, yield and quality attributes of garden pea as influenced by organic amendments and biofertilizers. Indian Journal of Horticulture 63(4), 464-66.

Bhattacharyya, P., Jain, R.K., Paliwal, M.K., 2000. Biofertilizers for vegetable. Indian Horticulture 45, 12-13. 
Chattoo, M.A., Ahmad, N., Narayan, S., Faheema, S., 2003. Influence of organic manures on cabbage cv. Golden Acre, 94. In: Souvenir national seminar on organic products and their future prospectus, October 21-22, 2003, S.K. University of Agricultural Sciences \& Technology of Kashmir, Shalimar, Srinagar (J\&K), India.

Chopra, S.L., Kanwar, J.S., 1983. Analytical agriculture chemistry, Kalyani Publishers. Ludhiana, Punjab, India, 341-342.

Dar, R.A., Gupta, A.K., Samnotra, R.K., 2010. Effect of integrated nutrient management on seed yield contributing parameters of okra. Asian Journal of Horticulture 4(2), 263-266.

Gopalakrishnan, T.R., 2007. Vegetable crops. Horticulture science series, New India Publishing Agency, New Delhi, 32-33.

Kızılkaya, R., 2008. Yield response and nitrogen concentrations of spring wheat (Triticum aestivum) inoculated with Azotobacter chroococcum strains. Ecological Engineering 33, 150-156.

Latrach, L., Farissi, M., Mouradi, M., Makoudi, B., Bouizgaren, A., Ghoulam, C., 2014. Growth and nodulation of Alfalfarhizobia symbiosis under salinity: electrolyte leakage, stomatal conductance, and chlorophyll fluorescence. Turkish Journal Agriculture 38, 320-326.

Ojoniyi, S.O., 2000. Effect of goat manure on soil nutrient and okra yield in a rain forest area of Nigeria. Applied Tropical Agriculture 5, 20-23.

Paramasivan, M., Jawahar, D., Krishnamoorthi, V.V., 2005. Effect of organic manures and inorganic fertilizers on yield and economics of okra in an alfisol of Tambiraparani tract. South Indian Horticulture 53(1-6), 312-315.

Parmar, D.K., 2014. Yield produce quality and soil health under vegetable cropping systems as influenced by INM in mid hill zone of Himachal Pradesh. Journal of the Indian society of Soil Science 62, 45-51.

Sharma, D.P., Prajapati, J.L., Tiwari, A., 2014. Effect of NPK, vermicompost and vermiwash on growth and yield of okra. International Journal of Basic and Applied Agricultural Research 12(1), 5-8.

Subbarao, T.S.S., Ravi Shankar, C., 2001. Effect of organic manures on growth and yield of brinjal. South Indian Horticulture 49 (Special), 288-291.

Verma, T.S., Thakur, P.C., Singh, A., 1997. Effect of biofertilizers on vegetables and seed yield of different crops. Vegetable Science 24(1), 1-3.

Yadav, S.C., Yadav, G.L., Gupta, G., Prasad, V.M., Bairwa, M., 2016. Effect of integrated nutrient management on quality and economics of okra (Abelmoschus esculentus (L.) Moench). International Journal of Farm Sciences 6(3), 233-237. 